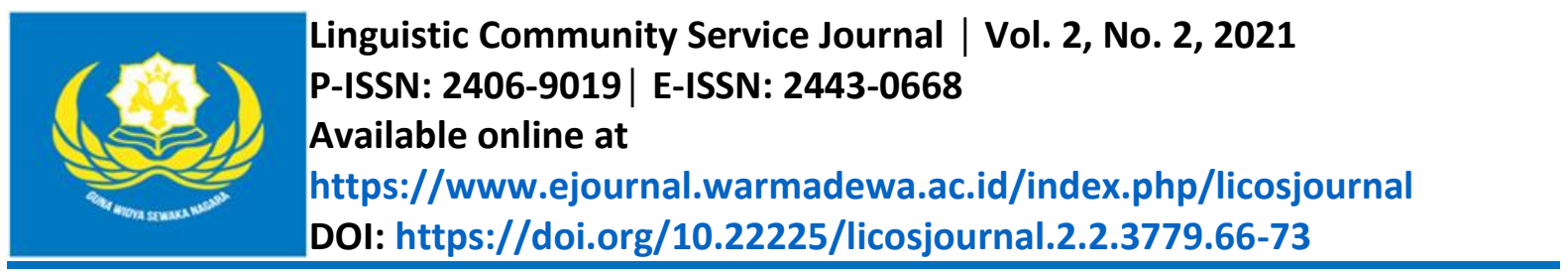

\title{
PEMASARAN PRODUK BERBASIS ONLINE BAGI PENGUSAHA RITEL MANDIRI DI DESA PANCASARI, BULELENG
}

\author{
I Made Astu Mahayana*, I Gusti Ayu Agung Dian Susanthi, \\ Ni Kd Sioaji Yamawati, I Wayan Budiarta, I Nyoman Mardika \\ Universitas Warmadewa Denpasar, Bali-Indonesia \\ *astumahayana@gmail.com
}

\begin{abstract}
Abstrak
Kehidupan New Normal kembali memberikan harapan bagi para pedagang di Desa Pancasari, Sukasada, Buleleng, Bali. Roda perekonomian kembali berputar, tentunya dengan menerapkan protokol kesehatan, para pedagang diijinkan untuk membuka usahanya kembali. Hal ini merupakan tantangan baru bagi pemilik retail; mereka harus memikirkan berbagai cara untuk memulai bisnisnya kembali yang selama beberapa bulan tidak beroperasi. Bisnis online adalah sebuah solusi terbaru di era society 5.0 ini. Produk atau jasa yang diiklankan (dipasarkan) secara online, tentunya harus menarik sehingga dapat diminati oleh para pembeli. Produk tersebut dapat ditawarkan secara online melalui media sosial. Hal ini merupakan pengalaman baru bagi pemilik retail, khususnya di desa Pancasari Kecamatan Sukasada, Buleleng yang mana biasanya menawarkan produk dagangannya secara konvensional. PKM ini dilakukan dengan tujuan untuk membantu pengusaha retail mandiri di Desa Pancasari, Kecamatan Sukasada Kabupaten Buleleng, yang belum pernah mengenal pemasaran secara online. PKM ini dilaksanakan dengan mendata pengetahuan mitra, mensosialisasikan kepada mitra, memberikan pelatihan kepada mitra, dan memantau perkembangan bisnis mitra. Berdasarkan hasil pembahasan di atas, dua produk yaitu minuman kopi dan bumbu makanan memiliki fitur khas pada pilihan kata yang digunakan. Pada produk minuman kopi, kata kerja yang dipilih yaitu nikmati, cicipi, dan rasakan. Sementara kata sifat yang dipilih yaitu nikmat, enak, khas, dan sempurna. Pada produk bumbu/makanan, kata kerja yang dipilih yaitu coba, rasakan, dan cicipi. Sedangkan kata sifat yang dipilih yaitu nikmat, enak, khas, dan terbaik.
\end{abstract}

Kata Kunci: Bahasa Iklan, Pedagang, Sosial Media

\begin{abstract}
New Normal life has again given hope to traders in Pancasari Village, Sukasada, Buleleng, Bali. The wheels of the economy are turning again, of course, by implementing health protocols, traders are allowed to reopen their businesses. This is a new challenge for retail owners; they had to think of various ways to restart a business that had been out of operation for several months. Online business is the latest solution in this era of society 5.0. Products or services advertised (marketed) online, of course, must be attractive so that they can be of interest to buyers. These products can be offered online through social media. This is a new experience for retail owners, especially in the village of Pancasari, Sukasada District, Buleleng which usually offers its merchandise conventionally. This PKM is carried out with the aim of helping independent retail entrepreneurs in Pancasari Village, Sukasada District, Buleleng Regency, who have never been familiar with online marketing. This PKM is carried out by recording partner knowledge, disseminating information to partners, providing training to partners, and monitoring partner business developments. Based on the results of the discussion above, two products, namely coffee drinks and food seasonings, have distinctive features in the choice of words used. In coffee drink products, the verbs chosen are enjoy, taste, and feel. While the selected adjectives are delicious, delicious, distinctive, and perfect. In seasoning/food products, the verbs chosen are try, taste, and taste. While the selected adjectives are delicious, delicious, distinctive, and best.
\end{abstract}

Keywords: Advertising Language, Merchant, Social Media

\section{PENDAHULUAN}

Desa Pancasari adalah desa di kecamatan Sukasada, Buleleng, Bali, Indonesia. Desa ini terletak 850 meter dari permukaan laut. Selain itu, letak desa ini dekat dengan Taman Raya Bedugul dan 
Objek Wisata Bali Hultura. Desa ini terdiri atas lima dusun, yaitu Buyan, Dasong, Karma, Lalang Linggah, dan Peken dengan jumlah penduduk 4061 jiwa (Tabel Data Kependudukan Berdasar Populasi Per Wilayah, n.d.) yang sebagian besar berprofesi sebagai petani, karyawan, dan wiraswasta.

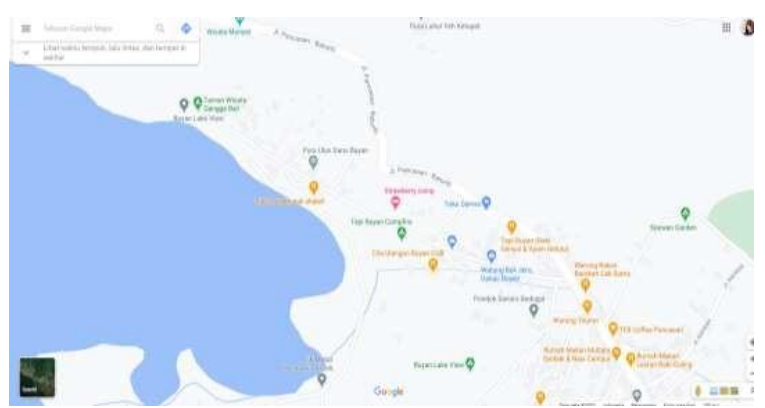

Gambar 1. Peta Lokasi Desa Pancasari

Selain itu Desa Pancasari merupakan desa yang biasa dikatakan memiliki tempat yang strategis, karena lokasinya dekat dengan perbatasan Tabanan-Buleleng. Oleh karena itu, desa ini biasanya menjadi tempat persinggahan bagi mereka yang ingin mengunjungi keluarga yang berada di Buleleng. Selain itu, terdapat pula pasar yang merupakan tempat kuliner bagi wisatawan yang datang dari Bali Handara setelah melakukan kegiatan seperti bermain golf, serta ritel mandiri yang menyediakan berbagai kebutuhan serta memiliki pangsa pasar yang cukup besar.

Ketika Covid 19 melanda seluruh dunia, desa ini mengalami pemerosotan perekonomian yang cukup signifikan. Ditambah lagi dengan diadakannya kegiatan Pembatasan Sosial Berskala Besar (PSBB) yang membatasi aktivitas dan waktu kegiatan masyarakat membuat perekonomian semakin terjun bebas. Hal ini berdampak langsung bagi para pengusaha UMKM, khususnya pengusaha ritel mandiri yang biasanya mengandalkan penjualan baik dari wisatawan local, maupun wisatawan asing. Hal ini mengakibatkan turunnya angka penjualan, serta lambatnya distribusi, sehingga menyebabkan karyawan yang bekerja di sector UMKM dirumahkan hingga di-PHK dengan angka sebesar 16,1\% (Rosita, 2020).

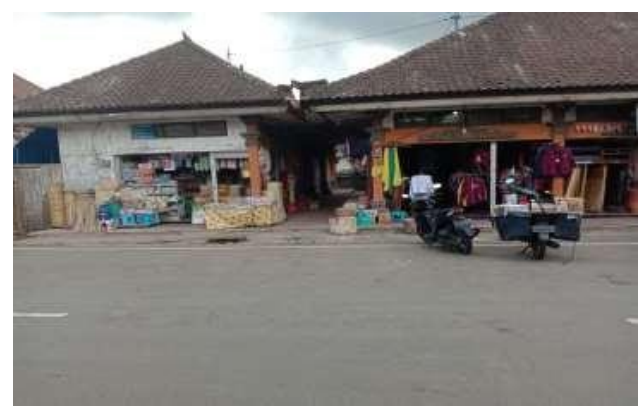

Gambar 2. Suasana Perekonomian pengusaha kecil di Desa Pancasari

Saat ini masyarakat di Indonesia sedang menjalani fase new normal. Menurut Achmad Yurianto, juru bicara pemerintah untuk penanganan Covid-19 new normal bukanlah situasi kembalinya hidup normal sebelum pandemi. Namun, new normal merupakan fase di mana kita harus mengubah kebiasaan lama menjadi kebiasaan baru untuk menciptakan situasi aman di tengah pandemic (Nurslalim, 2020). Ini mengajarkan kita bahwa kita harus mengubah gaya lama dalam beraktivitas yang sudah menjadi kebiasaan (habit) menjadi gaya baru, termasuk di dalamnya dalam rangka berinovasi di era 5.0. Hal ini juga berlaku bagi para pengusaha ritel mandiri di Desa Pancasari, Buleleng.

Di tengah maraknya pembangunan infrastruktur dan teknologi, pemilik ritel mandiri diharapkan mampu memanfaatkan teknologi dalam memasarkan produk mereka. Namun kenyataanya, pengelola/pemililik ritel serta para karyawannya tidak dapat memanfaatkan media social dengan baik. Bahkan ada salah satu karyawan yang tidak mengetahui apa itu media social. Hal ini sangat disayangkan mengingat saat ini kita sudah memasuki era teknologi 5.0. Oleh karena itu, pengelola retail diharapkan tidak hanya berdiam diri saja mengandalkan kedatangan wisatawan asing dan 
mengandalkan transaksi jual beli yang bisa dibilang masih tradisional. Dalam hal ini, pengelola dapat meningkatkan perkembangan bisnisnya dengan model B2B (Business to Business) dengan memanfaatkan platform e-commerce (online) yang disertai dengan beragam pilihan aplikasi seperti facebook, instagram, shopee, dll (Taufik \& Ayuningtyas, 2020). Bertitik tolak dari permohonan tersebut, Tim PKM memandang perlu melakukan pengabdian kepada masyarakat dengan topik PKM Pemasaran Produk Berbasis Online bagi Pengusaha Ritel Mandiri di Desa Pancasari, Buleleng.

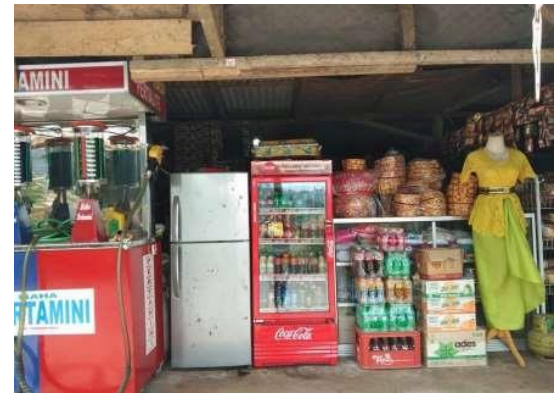

\section{Gambar 3. Kondisi ritel mandiri mitra}

\section{Permasalahan Mitra}

Seperti yang sudah dipaparkan di atas, Covid-19 sangat berpengaruh di berbagai sektor di seluruh pelosok Indonesia, khususnya di Bali. Salah satu desa yang mengalami pemerosotan ekonomi adalah desa Pancasari. Perekonomian di desa ini mengalami keterpurukkan. Bukan hanya pengusaha kecil di desa Pancasari, pengusaha menengah pun sangat merasakan pemerosotan penghasilan, salah satunya pengusaha ritel mandiri.

Ketika pemerintah menggalangkan kehidupan New Normal, roda perekonomian di desa Pancasari perlahan kembali berputar, tentunya dengan menerapkan protokol kesehatan, pengelola ritel mandiri telah memulai usahanya kembali. Hal ini tentunya merupakan tantangan baru bagi pengelola retail untuk memikirkan berbagai cara untuk meningkatkan bisnisnya kembali yang selama beberapa bulan mengalami kemerosotan ekonomi.

Bisnis online adalah sebuah solusi terbaru di era new normal ini. Produk atau jasa yang ditawarkan secara online, tentunya harus menarik sehingga dapat diminati oleh para pembeli. Produk tersebut dapat ditawarkan secara online melalui media masa, ataupun sosial media. Menurut Ningrum, Ayuningsasi, \& Wenagama (2020), media social dibagi menjadi dua yaitu:

i. profile-based: media sosial berdasarkan profil yang dapat digunakan untuk berinteraksi dengan konsumen, seperti: whatsapp, facebook, line, instagram, dll

ii. content-based: media social sebagai media pemasaran, seperti: youtube, instagram, twitter, dll.

Berdasarkan analisis situasi, ditemukan bahwa pengelola retail serta karyawan belum optimal dalam memanfaatkan media social. Hal ini disebabkan oleh ketidaktahuan mitra dalam memanfaatkan teknologi seperti gadget. Mitra menggunakan teknologi tersebut hanya untuk aktivitas menelpon. Sedangkan bagi para karyawan yang sudah mengenal media sosial, mereka hanya menggunakan media sosial sebagai sarana hiburan saja, seperti chatting, dan bermain games. Hal ini sangat disayangkan, apalagi saat ini kita sedang menghadapi krisis ekonomi dalam jangka waktu yang relative panjang.

Sesuai dengan pemaparan di atas, PKM ini dilakukan dengan tujuan untuk membantu mitra yang memiliki usaha ritel mandiri di Desa Pancasari, Kecamatan Sukasada Kabupaten Buleleng, yang belum pernah mengenal pemasaran secara online. Penggunaan bahasa iklan yang merupakan kajian Ilmu bahasa dan linguistik, berperan sangat penting dalam menunjang iklan produk/jasa yang ditawarkan. Susanthi, Mahayana, \& Kertiasih (2020) memaparkan komunikasi dapat dilakukan secara verbal atau non-verbal, tentu saja dalam melakukan komunikasi kita menggunakan bahasa untuk menyampaikan pesan kepada khalayak. Sejalan dengan gagasan tersebut bahasa sangat penting terkait dengan pemasaran produk. Penggunaan bahasa iklan dan fitur-fitur linguistik yang tepat dapat sangat membantu para pedagang untuk mengoptimalkan bisnisnya. Jefkins (1996) mengungkapkan bahwa teks iklan yang memiliki karakteristik, orisinal, dan persuasif dapat tercipta jika memenuhi syaratsyarat sebagai berikut. 
1. Teks iklan yang ditulis harus bersifat menjual, meskipun iklan hanya bertujuan untuk mengingatkan saja,

2. Rahasia keberhasilan iklan adalah pengulangan (repetition),

3. Orang tidak akan peduli untuk membaca teks iklan karena pesan iklan harus memanfaatkan secara maksimal kata-kata dan menyampaikan pesannya dengan segera,

4. Kata yang digunakan harus mudah dipahami, karena kata asing membuat calon konsumen merasa familiar. Sehingga perhatian terhadap iklan itu akan hilang,

5. Kata-kata singkat, kalimat-kalimat pendek, paragraf yang tidak terlalu panjang membantu menyampaikan pesan iklan serta memudahkan pembaca untuk memahami dan mengerti maksud teks iklan itu dengan cepat (Jefkins, 1996).

Sebelum kegiatan PKM, penyebaran questioner dilakukan. Hal ini dilakukan untuk mengetahui apakah para pedagang memiliki ketrampilan yang memadai terkait pemanfaatan e-commerce (pemasaran dan aktivitas berjualan berbasis online) dalam mepromosikan produk/jasa yang diiklankan. Setelah dilakukan pengamatan, penyebaran questioner Kembali dilakukan untuk mengukur kemajuan tingkat pemahaman mitra akan bahasa iklan yang tepat dan menarik untuk mempromosikan produk/jasa yang mereka tekuni. Penggunaan bahasa Iklan yang menarik dalam memasarkan produk atau jasa online merupakan suatu strategi yang baru yang dapat digunakan untuk menarik peminat atau pembeli di masa new normal. Hal ini juga merupakan strategi baru bagi pedagang atau pengusaha untuk memulai bisnis mereka yang terpuruk.

\section{METODE PELAKSANAAN}

Metode yang akan diterapkan dalam pelaksanaan PKM pada mitra di Desa Pancasari, Kecamatan Sukasada Buleleng adalah sebagai berikut.

Tabel 1. Metode Pelaksanaan

\begin{tabular}{|c|c|c|}
\hline No & Target Capaian & Langkah-Langkah Capaian \\
\hline 1 & $\begin{array}{l}\text { Mitra memahami } \\
\text { pentingnya penggunaan } \\
\text { social media dalam } \\
\text { pemasaran online } \\
\text { dengan } \\
\text { menggunakan bahasa iklan } \\
\text { yang menarik. }\end{array}$ & $\begin{array}{l}\text { - Mendata sejauh mana pengetahuan } \\
\text { mitra tentang platform e-commerce, } \\
\text { serta mendata fasilitas media yang } \\
\text { biasa/pernah/tidak pernah mereka } \\
\text { gunakan dengan menyebarkan } \\
\text { kuesioner (pre-kuesioner) } \\
\text { Menyosialisasikan kepada mitra } \\
\text { tentang manfaat social media, serta } \\
\text { penggunaan bahasa yang menarik } \\
\text { dengan memberikan contoh-contoh } \\
\text { iklan yang terdapat di e- commerce }\end{array}$ \\
\hline 2 & $\begin{array}{l}\text { Terbentuknya iklan baik } \\
\text { profile- based, maupun } \\
\text { content-based secara online } \\
\text { sehingga mitra mampu } \\
\text { memperluas jangkauan } \\
\text { promosi produknya. }\end{array}$ & 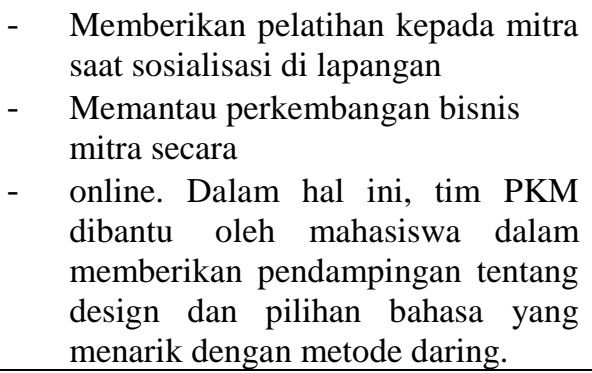 \\
\hline 3 & $\begin{array}{lr}\text { Mitra merasakan } & \\
& \text { manfaat } \\
\text { commerce } & \text { dalam } \\
\text { menjalankan bisnis. } & \\
\end{array}$ & $\begin{array}{l}\text { - Menyebarkan kuesioner untuk dapat } \\
\text { mengetahui sejauh mana program } \\
\text { PKM ini berkonstribusi kepada } \\
\text { mitra. }\end{array}$ \\
\hline
\end{tabular}

\section{HASIL DAN PEMBAHASAN}

Solusi permasalahan adalah dengan memilih media sosial yang tepat memasarkan produk secara online. Berdasarkan hasil survei dan wawancara yang dilakukan media social yang dapat digunakan untuk membantu pemasaran secara online adalah facebook dan IG. Pada media sosial tersebut dapat menampilkan foto-foto produk yang dijual,informasi harga ataupun deskripsi tentang 
produk tersebut. Deskripsi ataupun penggunaan bahasa iklan yang menarik sangat penting untuk diperhatikan untuk menarik minat konsumen. Leech dalam (Pratiwi, Sulatra, \& Candra, 2018) memaparkan bahwa Bahasa iklan memiliki fitur-fitur khas yang dapat dilihat dari berbagai aspek.

\section{Pilihan Kata}

Iklan adalah sebuah komunikasi persuasif yang dapat merubah perilaku khalayak. Sebuah iklan dikemas untuk menggiring pola pikir dan tindakan-tindakan yang diharapkan oleh pembuat iklan. Daya pikat iklan dibangun untuk mengingatkan khalayak pada citraan tertentu. Iklan memerlukan tampilan yang dikemas dengan bahasa merakyat, kontekstual dan 'kekinian'. Pada subbab ini akan dipaparkan pilihan kata yang dapat digunakan oleh mitra untuk memasarkan produkproduknya dengan menggunakan bahasa yang merakyat, kontekstual dan 'kekinian'. Sehingga diharapkan mampu menarik minat konsumen dan pengaruh pemilihan kata tersebut terhadap daya beli produk yang diiklankan.

\section{Pilihan Kata Kerja Produk Minuman Kopi}

Data menunjukkan ada beberapa kata kerja yang dapat digunakan dalam wacana iklan produk minuman kopi, yaitu: nikmati, cicipi, dan rasakan. Temuan ini mebuktikan bahwa kata kerja yang muncul ataupun dapat digunakan pada iklan atau produk minuman dapat berupa ajakan untuk mencoba, menikmati, mencicipi dan merasakan produk minuman yang ditawarkan sebagai contoh, untuk menawarkan produk kopi lokal Pancasari kata kerja yang dapat digunakan untuk menarik konsmumen untuk menikmati rasa yang enak dan khas dari produk tersebut adalah kata kerja nikmati, cicipi, rasakan.

Salah satu produk lokal yang dijual oleh mitra adalah kopi Sari Wangi, yaitu kopi khas Pancasari yang dibuat oleh penduduk local. Kopi ini merupakan kopi produksi home made yang diolah masih dengan cara yang konvensional. Biji kopi yang digunakan adalah biji kopi local yaitu ditanam oleh petani kopi Pancasari, dijemur di bawah matahari dan digiling dengan alat penggiling sehingga rasa yang ditawarkan cukup khas.

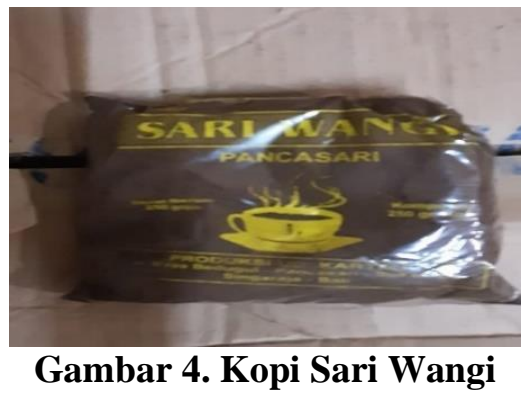

1) Kata Kerja nikmati

Contohnya:

- Nikmatilah kopi Sari Wangi, kopi khas Pancasari dengan cita rasa alami dapat membuat anda merasa ada di Pancasari.

- Nikmatilah kopi Sari Wangi denga cita rasa khas alam pegunungan Pancasari.

Kata kerja nikmatilah dapat digunakan membujuk konsumen untuk menikmati rasa kopi Pancasari dengan cita rasa yang alami. Dalam konteks ini iklan dapat meyakinkan konsumen bahwa rasa kopi pancasari menawarkan rasa yang berbeda dengan cita rasa khas yaitu cita rasa alam pegunungan Pancasari sehingga ketika konsumen adalah merupakan orang Pancasari yang berada jauh dan rindu akan kampung halaman kopi ini sangat cocok dinikmati untuk mengobati rindu dengan kampung halama, demikian pula dapat dijadikan oleh-oleh yang khas dari desa Pancasari.

2) Kata kerja rasakan

Contohnya:

- Rasakan kenikmatan kopi Sari Wangi, khas Pancasari dengan aroma dan rasa bak berada di alam pegunungan Pancasari

- Rasakan cita rasa Kopi Sari Wangi, khas Pancasari dengan kenikmatan yang alami 
Kata kerja rasakan dapat digunakan untuk mengajak konsumen untuk merasakan khasnya rasa kopi Pancasari. Dalam konteks ini, iklan dapat menawarkan konsumen rasa kopi yang khas sehingga kopi ini cocok diminum oleh pencita kopi jika ingin menikmati rasa yang khas dan berbeda dengan kopi produk lainnya.

3) Kata kerja cicipi

- Cicipi kopi Sari Wangi, kopi khas Pancasari yang nikmat dengan cita rasa khas pegunungan Pancasari

- Cicipi nikmatnya kopi Sari Wangi, dengan cita rasa yang nikmat bak berada di alam pegunungan Pancasari

Kata kerja cicipi dapat digunakan untuk mengajak konsumen untuk mencicipi khasnya rasa kopi Pancasari. Dalam konteks ini, iklan dapat mengajak konsumen untuk mencicipi rasa kopi yang nikmat dan khas sehingga kopi ini cocok diminum oleh penikmat kopi yang ingin mencicipi rasa yang khas dan berbeda dengan daerah lainnya.

\section{Pilihan Kata Sifat Produk Minuman}

Ada beberapa contoh kata sifat yang digunakan dalam wacana iklan produk minuman, yaitu: nikmat, enak, khas, sempurna, khas yang sesuai dengan produk kopi Pancasari. Beberapa contoh penggunaan kata-kata tersebut dapat dilihat pada pemaparan berikut.

1) Kata sifat nikmat

Contohnya:

- Kopi Sari Wangi yang nikmat dari Pancasari menawarkan cita rasa sejati pencinta kopi

Kata nikmat dapat digunakan membujuk konsumen untuk merasakan kopi Pancasari dengan cita rasa yang nikmat. Dalam konteks ini iklan dapat meyakinkan konsumen bahwa rasa kopi Pancasari menawarkan rasa yang nikmat yang sejati, yaitu rasa yang nikmat yang sejatinya diinginkan oleh pencinta kopi.

2) Kata sifat enak

Contohnya:

- Kopi Sari Wangi yang enak dari Pancasari memang tiada duanya

Kata enak dapat digunakan membujuk konsumen untuk merasakan kopi Pancasari dengan cita rasa yang enak. Dalam konteks ini iklan dapat meyakinkan konsumen bahwa rasa kopi Pancasari menawarkan rasa yang enak, dan tidak dimiliki oleh kopi lainnya. 'Enak tiada duanya' membujuk penikmat kopi untuk merasakapan kopi Pancasari.

3) Kata Kerja sempurna

Contohnya:

- Kopi Sari Wangi dari Pancasari memiliki cita rasa yang sempurna

Kata sempurna dapat digunakan membujuk konsumen untuk merasakan kopi Pancasari dengan cita rasa yang sempurna. Dalam konteks ini iklan dapat meyakinkan konsumen bahwa rasa kopi Pancasari, membujuk penikmat kopi untuk mencoba rasa kopi Pancasari yang cita rasa sempurna. Kata yang dipilih dapat berupa kata yang menggambarkan cita rasa produk minuman yang ditawarkan

4) Kata sifat khas

Contohnya:

- Kopi Sari Wangi Pancasari denga cita rasa yang khas membuat anda merasakan nikmatnya kopi alam pegunungan Pancasari

Kata khas dapat digunakan membujuk konsumen untuk merasakan kopi Pancasari dengan cita rasa yang khas. Dalam konteks ini iklan dapat meyakinkan konsumen bahwa rasa kopi Pancasari menawarkan rasa yang khas dan tidak ditemukan di kopi produk daerah lainnya.

\section{Pilihan Kata Kerja Produk Bumbu/makanan}

Data menunjukkan ada beberapa kata kerja yang dapat digunakan dalam wacana iklan produk bumbu makanan, yaitu: coba, rasakan, dan cicipi. Temuan ini mebuktikan bahwa kata kerja yang 
muncul ataupun dapat digunakan pada iklan atau produk bumbu dapat berupa ajakan untuk mencoba, menikmati, mencicipi dan merasakan produk bumbu yang ditawarkan sebagai contoh, untuk menawarkan produk gula aren lokal Pancasari kata kerja yang dapat digunakan untuk menarik konsmumen untuk menikmati rasa yang enak dan khas dari produk tersebut adalah kata kerja coba, nikmati, rasakan.

Gula aren adalah produk lokal yang dijual oleh mitra. Gula aren yang dijual merupakan produk yang dibuat oleh penduduk lokal Pancasari.

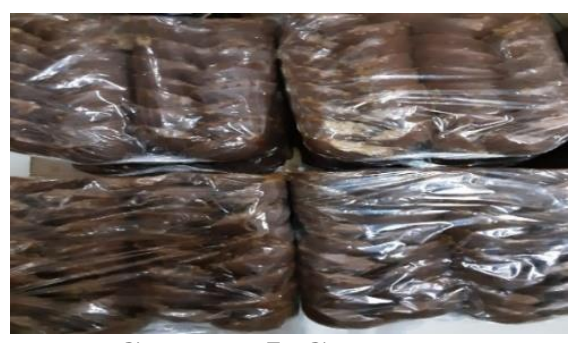

Gambar 5. Gula aren

1) Kata Kerja coba

Contohnya:

- Cobalah Gula Aren Pancasari yang enak dan lembut tanpa bahan pengawet

Kata kerja cobalah dapat digunakan membujuk konsumen untuk mencoba rasa gula aren dengan cita rasa yang enak dan tanpa bahan pengawet. Dalam konteks ini iklan dapat meyakinkan konsumen bahwa rasa gula aren yang enak dan lembut dan dibuat tanpa bahan pengawet dapat menarik minat konsumen

2) Kata kerja rasakan

Contohnya:

- Rasakan kenikmatan gula Aren Pancasari

Kata kerja rasakan dapat digunakan untuk mengajak konsumen untuk merasakan gula aren Pancasari. Dalam konteks ini, iklan dapat menawarkan konsumen rasa gula aren yang enak sehingga jika ingin menikmati rasa yang khas dan berbeda dengan gula aren produk lainnya.

3) Kata kerja cicipi

Contohnya:

- Cicipi gula aren khas Pancasari yang nikmat dengan cita rasa khas Pancasari

Kata kerja cicipi dapat digunakan untuk mengajak konsumen untuk mencicipi khasnya rasa gula aren Pancasari. Dalam konteks ini, iklan dapat mengajak konsumen untuk mencicipi rasa gula aren yang nikmat dan khas bagi konsumen yang ingin mencicipi rasa yang khas dan berbeda dengan daerah lainnya. Setelah kalimat pedagang bisa menambahkan deskripsi tentang produk ini misalnya: gula aren yang lembut dan enak khas Pancasari ini cocok disajikan dengan jaje Bali, menambah rasa enak es daluman dan sebagainya.

\section{Pilihan Kata Sifat Produk Bumbu/Makanan}

Ada beberapa contoh kata sifat yang digunakan dalam wacana iklan produk makanan, yaitu: nikmat, enak, khas, terbaik yang sesuai dengan produk kopi Pancasari. Beberapa contoh penggunaan kata-kata tersebut dapat dilihat pada pemaparan berikut.

1) Kata sifat nikmat

Contohnya:

- Gula Aren yang nikmat dari Pancasari menawarkan cita rasa sejati

Kata nikmat dapat digunakan membujuk konsumen untuk merasakan gula aren dengan cita rasa yang nikmat. Dalam konteks ini iklan dapat meyakinkan konsumen bahwa rasa kopi Pancasari menawarkan rasa yang nikmat yang sejati, yaitu rasa yang nikmat yang sejatinya diinginkan oleh konsumen. 
2) Kata sifat enak

Contohnya:

- Gula aren yang enak dari Pancasari memang tiada tandingannya

Kata enak dapat digunakan membujuk konsumen untuk merasakan gula aren dengan cita rasa yang enak. Dalam konteks ini iklan dapat meyakinkan konsumen bahwa rasa gula aren Pancasari menawarkan rasa yang enak, dan tidak dimiliki oleh gula aren lainnya. 'Enak tiada tandingannya' membujuk konsumen merasakan gula aren Pancasari.

3) Kata Sifat khas

Contohnya:

- Gula aren dari Pancasari memiliki cita rasa yang khas

Kata khas dapat digunakan membujuk konsumen untuk merasakan gula aren Pancasari dengan cita rasa yang khas. Dalam konteks ini iklan dapat meyakinkan konsumen bahwa rasa gula aren Pancasari menawarkan rasa yang tidak dimiliki oleh produk daerah lainnya.

4) Kata sifat superlatif terbaik

Contohnya:

- Gula aren Pancasari denga cita rasa terbaik tidak ada duanya

Kata terbaik memiliki makna paling baik diantara yang lainnya. Pengiklan dapat menggunakan kata ini untuk menonjolkan produk yang ditawarkan sebagai yang terbaik jika dibandingkan dengan produk serupa lainnya. Pengiklan dapat menggunakan kata untuk menunjukkan kepercayaan diri dan optimis denga kualitas produk yang ditawarkan.

\section{SIMPULAN}

Iklan adalah sebuah komunikasi persuasif yang dapat merubah perilaku khalayak. Sebuah iklan dikemas untuk menggiring pola pikir dan tindakan-tindakan yang diharapkan oleh pembuat iklan. Daya pikat iklan dibangun untuk mengingatkan khalayak pada citraan tertentu. Iklan memerlukan tampilan yang dikemas dengan bahasa merakyat, kontekstual dan 'kekinian'. Berdasarkan hasil pembahasan di atas, dua produk yaitu minuman kopi dan bumbu makanan memiliki fitur khas pada pilihan kata yang digunakan. Pada produk minuman kopi, kata kerja yang dipilih yaitu nikmati, cicipi, dan rasakan. Sementara kata sifat yang dipilih yaitu nikmat, enak, khas, dan sempurna. Pada produk bumbu/makanan, kata kerja yang dipilih yaitu coba, rasakan, dan cicipi. Sedangkan kata sifat yang dipilih yaitu nikmat, enak, khas, dan terbaik.

\section{DAFTAR PUSTAKA}

Jefkins, F. (1996). Periklanan. Jakarta: Rajawali Pers.

Ningrum, G. A. P. D. V., Ayuningsasi, A. A. K., \& Wenagama, I. W. (2020). Faktor- Faktor yang Mempengaruhi Pendapatan Pedagang Bidang Fashion di Kota Denpasar. E-Jurnal Ekonomi Pembangunan, 9(1), 147-176.

Nurslalim, I. (2020). New Normal Sebagai Gaya Hidup. DetikNews. Retrieved from https://news.detik.com/kolom/d-5097523/new-normal-sebagai-gaya-hidup

Pratiwi, D. P. E., Sulatra, I. K., \& Candra, K. D. P. (2018). Mengupas Makna dan Menguak Ideologi di Balik Iklan Pariwisata Bali. Denpasar: Pustaka Larasan.

Rosita, R. (2020). Pengaruh Pandemi Covid-19 Terhadap Umkm Di Indonesia. Jurnal Lentera Bisnis, 9(2), 109.

Susanthi, I. G. A. A. D., Mahayana, I. M. A., \& Kertiasih, N. N. (2020). Pengajaran ESP Bagi Polisi Pariwisata di Sekolah Tinggi Polda Bali. Linguistic Community Service Journal, 1(1), 10-18.

Tabel Data Kependudukan berdasar Populasi Per Wilayah. (n.d.). Retrieved February 22, 2021, from http://pancasari-buleleng.desa.id/index.php/first/wilayah

Taufik, \& Ayuningtyas, E. A. (2020). Dampak Pandemi Covid 19 Terhadap Bisnis Dan Eksistensi Platform Online. Jurnal Pengembangan Wiraswasta, 22(01). 